\title{
TRADE UNION CONTROL IN THE CONTEXT OF TRADE UNION RELATIONS WITH PUBLIC ADMINISTRATION ENTITIES IN UKRAINE
}

\author{
Petro Lukyanchuk ${ }^{1}$ \\ ${ }^{\text {I}}$ Postgraduate student, Master of Public Administration, Director, State Archives of Odessa Region, Odessa, \\ Ukraine, e-mail:lp110760@ukr.net
}

\begin{abstract}
At the present stage of development of the trade union movement in Ukraine, the issues of determining the place and role of trade unions in the system of public administration as a subject of public administration and the institution of civil society are relevant. The lack of legal recognition of social partnership, and its replacement by social dialogue has led to a decrease in the influence of trade unions on social protection and the lack of trade union control. The latter has been replaced by public control exercised in Ukraine by various public associations. The aim of the article: As a result, trade unions began to participate as advisory bodies rather than as defenders of workers' labor rights. Accordingly, the relations with the subjects of public administration have changed. The aims of the article: to demonstrate that not only in the Ukrainian practice of public administration, but also in the science of public administration, no attention is paid to the problem of trade union control and the relationship between trade unions and public administration entities. Object of research: trade unions as a subject of public administration. Research methodology: a review of Ukrainian literature sources on trade union control and its impact on the relationship of public administration. The results obtained: in the Ukrainian science of public administration there are no publications on trade union activities and trade union control; the mechanisms for building relationships between trade unions and public administration entities are not defined; there is a constant perception that trade unions are public associations and their main role is to conduct a dialogue between employers, authorities and employees; there is no clear conceptual view of the trade union control process, which causes many legal conflicts. Practical significance: scientific substantiation of the use of the concept of "trade union control" in legal practice and in the activities of public administration, its clear definition makes it possible to influence the rights of workers and influence the development of social policy by public administration.
\end{abstract}

Keywords: public administration, trade union control, public control, interaction, subjects of public administration.

JEL Classification: J50, J58, H19

Formulas: 0; fig.: 0; tabl.: 0; bibl.: 14

Introduction. In Ukrainian scientific publications, the problem of trade union control in the field of public administration is mostly about building certain relationships between various public administration entities, trade unions, their members and employers. This is most often associated with the understanding of social partnership, which is not legally recognized in Ukraine, but is a category of scientific fields (including public administration), as well as a category of politicians. However, it should be noted that the changes taking place in recognizing the role of trade unions in building social partnership are primarily related to the deep demographic, migration, structural and economic and other processes of global scale. In these circumstances, trade unions are required to seriously reassess not only the forms and methods of control and protection in the field of socio-economic relations, but also the ideology of this control, which is quite acceptable for traditional 
industrial society, but no longer corresponds to democratic governance. Under conditions of intensive democratic, social, state and legal transformations taking place in Ukraine, the role of the state, its functions, and, accordingly, stateadministrative relations change significantly, which necessitates the simultaneous solution of two interrelated tasks: building the foundations of independent state and radical reform of the political sphere and socio-economic relations. Their solution is inextricably linked with the need to find compromises between the participants of socio-economic relations, finding the optimal balance of interests.

Relevance is determined by the consistent implementation of the course of democratic reforms in Ukraine, objective processes of development and modernization of society as a whole, the transition from command-administrative to democratic, legal system of public administration. The role of independent and capable trade unions, as an important institution of civil society that protects the rights and freedoms of citizens in the field of labor relations, is especially important in the formation of democracy and market economy in Ukraine. Creating powerful, influential unions that can effectively defend the interests of workers is an integral attribute of a civilized state. Given the tendency to increase the role of trade unions in the system of social partnership, increasing trust in them by employees in the global financial crisis, the issue of cooperation of labor collectives with trade unions is of particular importance.

In the Ukrainian science of public administration, no attention is paid to this research. In other fields of science, there are about 10 scientists who studied this problem from 1991 to 2017. At the present stage of reducing the role of trade unions in Ukraine, transferring their activities to the plane of public associations, the existence of legal conflict, it is important to clearly define "Trade union control" and "public control" in the process of trade union interaction with public administration entities.

Literature review. It should be noted that scientific developments in the field of trade union activity, trade union control in Ukrainian science are quite small. There are a small number of scientists who have thoroughly studied this issue. The issue of trade union control and its place in the system of public administration is considered from several positions, in particular: the activities of tripartite commissions with the participation of the government, employers and trade unions, which were concluded annually (Protsyuk, 2010); analysis of problematic issues of trade union control and its characteristics in the administrative and legal aspect (Shakirova, 2012); the role of trade unions in collective bargaining on the example of comparing the practice of social partnership between Ukraine and Germany (Shereper et al., 2013); problems of trade union public control in the context of the processes of formation of a democratic state governed by the rule of law (Solominchuk, 2014).

Particular attention needs to be paid to the processes of building relations between the government and trade unions, as well as public institutions and public authorities, which relate not only to legal or organizational mechanisms of public 
administration, but also a wide range of trade unions in Ukraine. Ukrainian scientists have different attitudes to this issue. Thus, F. Tsesarsky (2004) states that relations with the executive authorities and employers' organizations are built in order to better protect the rights and interests of employees and prevent violations of labor rights. In his opinion, cooperation with state bodies is important from the standpoint of building joint actions, manifestations of a principled position in defending and protecting the rights of workers. This is considered to be a range of "means of influencing employers, regional and local governments, and central and local executive bodies." V. Nikiforov (2005) also considers building the relationship of trade unions with the state and its bodies an important process. Emphasis is placed on the fact that "all these relations are designed to ensure the smooth implementation of the basic individual legal relationship between employee and employer" (Nikiforov, 2005), and the state must "determine the rights, duties and responsibilities of trade unions, and must determine their forms implementation in procedural norms and legal relations "(Nikiforov, 2005).

O. Tupitsa (2009) believes that trade unions are forced to interact with the public administration apparatus to address many issues, and this apparatus should be interested in partnership with trade unions. O. Movchan (2004) proves the expediency of changes in the beliefs of professional organizations regarding their ability to defend the interests of employees. A. Shakirova (2012) writes about the formation of a certain standardization of control functions of trade unions, their maximum approximation to the urgent needs of the social, economic, administrative and managerial spheres, ensuring the legality and efficiency of their implementation. The analysis of scientific sources showed the lack of clear definitions of the terms "trade union control", "public control", "protection of rights by trade unions". The role of trade unions in the modern system of public administration is not studied.

Ambiguous interpretation of trade unions not only in the context of public administration, but also in the context of labor law, as their activities are on the border of two industries, according to the author of the dissertation. Thus, Yu. Dmytrenko $(2009$, p. 111) defines trade unions in the context of legislation and provides a classification of trade unions depending on the powers. Unlike other authors, he states that trade unions monitor compliance with labor legislation and regulations on labor protection, control housing and communal services, manage sanatoriums, clinics and rest homes, cultural and educational institutions, tourists are in their possession.

M. Inshin and others. (2016) refers trade unions to the institution of social partnership, which is understood as "a set of labor law norms that are designed to regulate social partnership relations. This institute envisages the formation of mechanisms of social partnership, including dialogue, cooperation of all stakeholders on labor issues. " These scholars (M. Inshin et al. 2016, p. 29) distinguish, respectively, the institute of state supervision and public control over compliance with labor law, which is interpreted as a set of rules of law designed to regulate 
relations on state supervision (control), public control in compliance with labor legislation. This institution has a cross-sectoral nature and is governed by labor and administrative law. Other scholars note that "the state recognizes trade unions as authorized representatives of workers and defenders of their labor, socio-economic rights and interests in public authorities and local governments, in relations with the owner or his authorized body, as well as other associations of citizens" (In Kucher et al., 2017, pp. 127).

V. Pastushenko (2004) considers the role of trade unions in providing social protection for workers. We are talking about the creation and development of the welfare state. The role of trade unions is seen in providing social protection by initiating the development of concepts, strategies, programs, etc. This mostly concerns the processes of state regulation. Attention is focused on the expediency of trade union reform. V. Kontsur (2006) emphasizes the need to develop a concept of the place and role of trade unions in relations with the state, employers and trade union members. The problems of trade unions in their educational work are considered little studied.

B. Bezzub and others. note that "Expressing the will of the labor collective, the trade union body may act both on its own behalf (exercise of public control and supervision) and on behalf of the relevant collective (development and signing of a collective agreement)." This understanding of the activities and powers of trade unions gives greater powers to trade unions, however, is equal to any public organization that can conduct business without tax.

Aims. The aims of the article: to demonstrate that not only in the Ukrainian practice of public administration, but also in the science of public administration, no attention is paid to the problem of trade union control and the relationship between trade unions and public administration entities. Object of research: trade unions as a subject of public administration.

Methods. Research methodology: a review of Ukrainian literature sources on trade union control and its impact on the relationship of public administration.

Results. In several branches of science, attention is paid to the issues of trade union activity and trade union control, in particular in the context of: labor law and with emphasis on the protective function of trade unions and interaction in this aspect with government agencies; formation of trade union activity and trade union control with an emphasis on participation in advisory bodies; social and labor relations; interaction of trade unions and the political system of the state; trade union control in the field of social partnership. Most research on trade union activities has been conducted in such areas as: law; history; economy; political science - in which dissertations on this issue are defended. In the field of public administration, there are some publications, which indicates the lack of research on this issue and the lack of scientific support in the context of developing mechanisms for trade union control and protection of rights in the field of public administration. In fact, in scientific sources, public administration influence on the development of trade union control 
from several positions: the formation of a nationwide approach to the place and role of trade unions in the system of public administration; building relationships with public authorities and political parties; trade union finance management; processes of ideologizing the activities of trade unions and their merging with the state apparatus and with the owners of enterprises where trade unions are created. It is shown that these problems are relevant for all periods of trade union development and are relevant at the present stage. However, they are little studied in various fields of science. This issue has not been studied in the science of public administration. No attention is paid to the problems of professionalism of trade unionists in building the interaction of public and public administration bodies with trade unions.

In scientific sources, the interpretation of the essence of trade unions comes from several positions, in particular as: public association; self-organizational education; public control; form of self-organization of employees; one of the powerful forms of social and economic organization of society; economic actors; as equal subjects to basic political institutions, such as political parties, public organizations, state bodies, as trade unions go beyond their socio-economic functions; political institute; the largest public association; an association of employees aimed at increasing the competitiveness of the enterprise. This demonstrates, on the one hand, the role of trade unions in public administration, on the other hand, the lack of systematic research on the role of modern trade unions and the identification of clear mechanisms for trade union control and interaction of trade unions with public administration.

Assessing the state of scientific development of trade union control and protection of interests in the social partnership system, it should be noted that the multifaceted concepts of "civil society", "social partnership", "trade unions", "public control" led to the emergence of different concepts of their study, significant differences in approaches to understanding concepts, their content. This gives grounds to state that there is no holistic concept of analysis of the functioning and development of trade unions in the transformational period of society. In particular, the study of trends and problems, prospects for development, taking into account the peculiarities of modern concepts of public administration (the theory of political networks, the concept of democratic governance, etc.). The focus is on the mechanisms of trade union control and protection of interests in the social partnership system. If the first aspect is of purely practical importance, the second defines the methodological framework on which there is coordination between partners at the highest (national) level of both income distribution and socio-economic policy in general, including the development of basic criteria and indicators of social justice and measures. protection of the interests of the subjects of labor relations.

Trade unions are created and operate in the field of labor in order to represent, control and protect the interests of employees in socio-economic relations. They are perhaps the only surviving mass organization, an institution through which a person satisfies the need for collectivism, group support, and so on. Trade union activities 
take on different forms in enterprises based on different types of ownership: the protection of the rights and interests of workers in state-owned enterprises often takes on a political color, as the employer is a state with not only economic but also political power; on collective property, there is no employer opposing the workers, there is always possible arbitrariness against individual employees by hired administrators, as well as by representative bodies in the collectives; strong professional associations of workers in private enterprises are needed to combat encroachments on their interests by various external forces.

At many enterprises, there is a real fusion of administration and trade union leaders. In reality, the trade union took over the functions of the social department of enterprises. The resources of a public organization (independence, the voluntary nature of membership, the limits of militancy, etc.) have become administrative resources and are used by managers at various levels (especially senior) to effectively manage the organization. Partnerships between trade unions and entrepreneurs are not easy. The union, by its nature, should be the independent intermediary in the relationship between workers, the state and the employer, which partially eliminates this imbalance. Therefore, there is a need for a clear formulation of the role and place of the trade union in the social and labor process, defining the functions, tasks and resources of trade union activity.

On the basis of the analysis the spheres of application of trade union control over are observed: observance by the employer of the legislation on work and on labor protection; provision at the enterprise, institution or organization of safe and harmless working conditions, industrial sanitation; correct application of the established conditions of payment; elimination of the revealed shortcomings. At the same time, if the employer complies with labor legislation, we have two main areas of trade union control: establishing working conditions (which is the main area of control of the trade union body) and applying working conditions established not only by labor legislation but also by local regulations and direct agreement, employee and employer.

In order to detail the list of control procedures, ensuring its comprehensiveness and systematic implementation, the scope of the scope of trade union control was determined and systematized in accordance with the commissions of the trade union committee: on organizational work; on preparation and control over the implementation of the collective agreement; on social and household issues; on labor protection; legal; on work with public catering establishments and trade establishments, etc.Conclusion. Analysis of scientific literature and abstracts of dissertation research has shown the lack of a broad source base on this issue in Ukrainian science. In several fields of science (law; history; economics; political science - in which dissertations on this issue are defended), attention is paid to the issues of trade union activity and trade union control, in particular in the context of labor law and with emphasis on the protective function of trade unions. state bodies; formation of trade union activity and trade union control with an emphasis on 
participation in advisory bodies; social and labor relations; interaction of trade unions and the political system of the state; trade union control in the field of social partnership. In the field of public administration, there are some publications, which indicates the lack of research on this issue and the lack of scientific support in the context of developing mechanisms for trade union control and protection of rights in the field of public administration.

Conclusion. Analysis of scientific literature and abstracts of dissertation research has shown the lack of a broad source base on this issue in Ukrainian science. In several fields of science (law; history; economics; political science - in which dissertations on this issue are defended), attention is paid to the issues of trade union activity and trade union control, in particular in the context of labor law and with emphasis on the protective function of trade unions. state bodies; formation of trade union activity and trade union control with an emphasis on participation in advisory bodies; social and labor relations; interaction of trade unions and the political system of the state; trade union control in the field of social partnership. In the field of public administration, there are some publications, which indicates the lack of research on this issue and the lack of scientific support in the context of developing mechanisms for trade union control and protection of rights in the field of public administration.

These developments will provide an opportunity to amend the legislation of Ukraine on trade unions and distinguish between the concepts of "trade union control" and "public control" in the activities of trade unions in cooperation with public administration.

\section{References:}

1. Protsyuk, S. (2010). Social partnership as a mechanism of social protection. Retrieved from: http://www.dridu.dp.ua/zbirnik/2010-01/10pslzzn.pdf

2. Shereper, I., \& Smokvina G. (2013). Experience of European countries in the development of social partnership in Ukraine. Economics: realities of time №4 (9). Retrieved from: https://economics.opu.ua/files/archive/2013/No4/189-194.pdf

3. Solominchuk, V. (2014). Trade union public control as an integral element of a democratic, legal state. Scientific journal of NPU named after MP Drahomanov. Series 18: Economics and Law. Vip. 26, 123-129. Retrieved from: http://enpuir.npu.edu.ua/bitstream/123456789/25688/1/S\%D0\%BElominchuk.pdf

4. Cesarsky, F. (2004). Protective function of trade unions, forms of its implementation. Yaroslav the Wise National Law Academy of Ukraine. Kharkiv.

5. Nikiforov, V. (2005). Protection of trade unions of social and labor rights of workers in a market economy (theoretical and legal aspect). Yaroslav the Wise National Law Academy of Ukraine. Kharkiv.

6. Tupitsa, O. (2009). Trade unions and the political system: the specifics of interaction in modern society. O. Honchar Dnipropetrovsk National University. Dnipro.

7. Movchan, O. Ukrainian Trade Unions in the Communist Party-Soviet System of Power (1920s). (2004). National Academy of Sciences of Ukraine. Institute of History of Ukraine. Kiev.

8. Shakirova, A. (2012). Problematic issues of trade union control in Ukraine (administrative and legal aspect). Scientific Bulletin of Uzhhorod National University. RIGHT series. Issue 19. Volume 3.

9. Dmitrenko, Yu. (2009). Labor law of Ukraine. Kiev. ЮринкомИнтер.

10. Inshin, M., Kostyuk L., \& Melnyk V. (2016). Labor law of Ukraine. Kiev. Center for Educational Literature. - 472 p., P. 29)

11. Kucher, V. and others. (2017). Labor law of Ukraine. Lviv. ЛьвДУВС.

12. Pastushenko, V. (2004). Organizational and economic mechanism for ensuring social protection of workers. Donetsk National University. Donetsk. 
13. Kontsur, V. (2006). Trade unions of Ukraine in the system of ideologizing society (1956 - 1964) Donetsk National University. Donetsk.

14. Bezzub, B., \& Mikhatulina, O. (2007). Labor law of Ukraine. Kiev. MAUP.

Received: August 11, 2020

Approved: September 15, 2020 